\title{
PERANCANGAN APLIKASI PENJUALAN HASIL PANEN DI INDONESIA BERBASIS ANDROID
}

\author{
Anna Karenina Jusuf ${ }^{1}$, Mei Lestari ${ }^{2}$, Ni Wayan Parwati ${ }^{3}$ \\ 1,2,3 Universitas Indraprasta PGRI \\ Jalan Raya Tengah No 80, Kelurahan Gedong, Pasar Rebo, Jakarta Timur \\ $\underline{1 \text { akarenina25@gmail.com }{ }^{2} \text { mei.lestari6@gmail.com }{ }^{3} \text { wayan.parwati@gmail.com }}$
}

\begin{abstract}
ABSTRAK
Indonesia merupakan negara agraris yang komoditas penduduk nya memiliki profesi sebagai petani. Dengan letak negara yang stategis dan berada pada garis khatulistiwa, menjadikan Indonesia memiliki iklim tropis dalam suatu kondisi yang sangat mendukung untuk berkembangnya sektor pertanian. Sektor pertanian di Indonesia memiliki cakupan yang sangat luas, meliputi: Padi, palawijaya, hortikultura, perkebunan, peternakan, budi daya ikan, penangkapan ikan, tanaman kehutanan dan kehutanan lainnya. Hal tersebut menjadikan sektor pertanian sebagai salah satu pilar yang mendukung pergerakan roda ekonomi di Indonesia. Berdasarkan hal tersebut, penulis menemukan ide untuk mengembangkan suatu perancangan aplikasi penjualan hasil panen yang diharapkan dapat membantu petani di Indonesia. Metode pengembangan yang digunakan yaitu metode Agile karena metode ini telah terbukti dapat bekerja dengan baik untuk berbagai project dengan unsur uncertainity. Hasil dari penelitian ini sangat bermanfaat untuk membantu petani di Indonesia dalam beradaptasi dengan perekonomian digital dan meninggkatkan penjualan hasil panen.
\end{abstract}

Kata Kunci: Penjualan, Petani, Sayur, Android

\begin{abstract}
Indonesia is an agrarian country whose population has a profession as a farmer. With the strategic location of the country and being on the equator, Indonesia has a tropical climate in a very supportive condition for the development of the agricultural sector. The agricultural sector in Indonesia has a very broad scope, including: rice, secondary crops, horticulture, plantations, animal husbandry, fish farming, fishing, forestry and other forestry crops. This makes the agricultural sector one of the pillars that support the movement of the economy in Indonesia. Based on this, the authors found an idea to develop an application design for selling crops that are expected to help farmers in Indonesia. The development method used is the Agile method because this method has been proven to work well for various projects with elements of uncertainty. The results of this study are very useful to help farmers in Indonesia adapt to the digital economy and increase sales of their crops.
\end{abstract}

Key Word: Sales, Farmer, Vegetable, Android

\section{PENDAHULUAN}

Sejak akhir tahun 2019, wabah penyakit Corona Virus 2019 (COVID-19) menyebar dengan cepat di seluruh dunia sehingga merugikan banyak profesi bahkan mengakibatkan terhambatnya pergerakan ekonomi di kebanyakan negara. Dengan terjadinya wabah COVID-19, aktifitas masyarakat sehari-hari berubah secara drastis, guna mengurangi persebaran virus tersebut pemerintah menerapkan Social Distancing atau Pembatasan Sosial dimana pengguna diharuskan menjaga jarak dan menghindari kerumunan atau tempat yang ramai. Hal tersebut berdampak terhadap banyak sektor per-ekonomian di Indonesia termasuk sektor pertanian yang terhambat dalam melakukan distribusi barang dan kegiatan jual beli.

Dalam masa pandemik ini, pemerintah menganjurkan masyarakat untuk tetap berada dirumah dan mewajibkan nya untuk menjaga jarak, menjadikan fungsional pasar tidak efektif dalam menjalankan fungsi distribusi, pasar merupakan media untuk menyalurkan atau memperlancarkan suatu barang atau jasa dari produsen kepada konsumen, dan mendekatkan jarak antara produsen dengan konsumen dalam melaksanakan transaksi (Aliyah, 2017). Oleh karena itu pasar menjadi sepi pengunjung yang menyebabkan toko dan pedagang tutup atau tidak berjualan. 
Indonesia dikenal sebagai negara agraris, yaitu negara yang sebagian besar masyarakatnya bermata pencaharian sebagai petani (Albdulrohim, 2015). Hal tersebut menyebabkan petani di Indonesia, khusus nya petani sayur mengalami kerugian, kerugian tersebut terjadi karena kondisi pasar yang sepi dan juga penerapan Pembatasan Sosial Berskala Besar (PSBB) yang menyebabkan pengiriman terhambat, sulit nya keluar masuk kendaraan antar kota dan pasar yang tutup lebih awal sehingga penjualan hasil panen terhambat didistribusikan kepada pelanggan.

Perkembangan bisnis saat ini sangat di dukung oleh adanya teknologi yang terhubung dengan internet, kedua hal tersebut memiliki pengaruh yang besar dalam berbisnis, Karena telah banyak masyarakat yang terkoneksi melalui smartphone, salah satu solusi yang dapat membantu permasalahan dibidang pertanian, dengan adanya perkembangan teknologi informasi yang pesat (Nyoman, 2017). Oleh karena itu tujuan dari penelitian ini adalah membantu petani sayur di Indonesia unutk ikut serta dalam perkembangan teknologi dengan cara menjual hasil panen nya melalui mobile aplikasi yang diharapkan dapat bermanfaat untuk mengjangkau lebih banyak pembeli dan dalam pergerakan perekonomian.

\section{METODE PENELITIAN}

Pada penelitian ini, penulis menggunakan metode penelitian Research and Development untuk menghasilkan produk dan untuk menguji efektivitas produk tersebut dengan menggunakan survei analisis permintaan agar dapat bekerja di masyarakat luas., peneliti berusaha untuk mendapatkan data yang memiliki kolerasi terhadap permasalahan yang diteliti sehingga pembahasannya fokus, terarah serta jelas dan tidak melebar terhadap bidang lain. Beberapa metode pengumpulan data yang digunakan oleh peneliti yaitu : Studi Pustakaan, Studi Literatur dan Observasi dimana peneliti mengumpulkan data beserta informasi yang relevan dengan cara mempelajari buku, e-book dan dokumentasi dari teknologi yang berkaitan dengan rumusan masalah yang diperoleh dari buku yang dimiliki penulis, dan dokumentasi resmi dari website teknologi yang digunakan pada perancangan aplikasi ini, selain itu penulis juga menguji aplikasi yang terkait dengan rumusan masalah penelitian ini serta membandingkan kelebihan dan kekurangan apa saja yang ada pada apliaksi tersebut. Pengujian aplikasi dilakukan agar persetujuan dari pengguna aplikasi diperoleh yang berlandaskan kepuasan pengguna demi menjaga kualitas aplikasi (Made, 2019)

Dalam pengembangan sistem pada aplikasi ini, peneliti menggunakan metode Agile, yang dimulai dengan Plan, design, develop, test, deploy, review, dan launch.

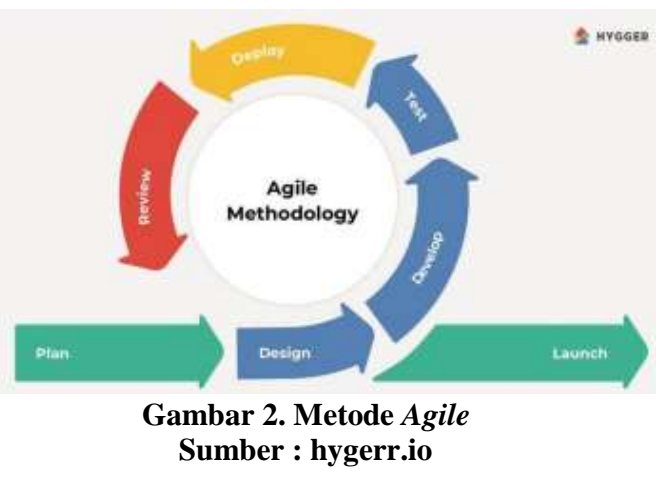

HASIL DAN PEMBAHASAN

Dengan dukungan teknologi yang saat ini bekembang sangat cepat, penulis memiliki keinginan untuk membantu petani sayur di Indonesia dalam menjual hasil panen nya agar perekonomian mereka tetap terjaga, penulis ingin membuat suatu aplikasi penjualan hasil panen petani sayur berbasis Android dimana semua petani sayur dapat menggunakannya kelak untuk menjual hasil panennya.

Dalam membangun aplikasi ini, penulis menemukan beberapa hal yang cukup challenging untuk diimplementasikan, seperti bagaimana membuat aplikasi ini dapat digunakana dengan mudah bagi para petani yang sudah memasuki tahap lanjut usia, lalu dalam proses pengkodeannya terdapat banyak hal yang harus diperhatikan oleh penulis seperti bahasa pemrograman yang digunakan, 
arsitektur dari aplikasi, pengelolaan background task, manajemen memori dan lain sebagainya karena Android merupakan suatu sistem operasi mobile dimana setiap penggunaan memorinya sangat diperhitungkan, jika hal tersebut diabaikan oleh penulis maka akan menyebabkan experience yang buruk sehingga pengguna meng-uninstall aplikasi tersebut.

Oleh karena itu dalam membangun aplikasi ini peneliti sangat memperhatikan penggunaan memori dan aspek lainnya agar pengguna memiliki pengalaman terbaik dalam menggunakan aplikasinya.

\section{Algoritma Tampilan OnBoarding}

1. User dapat melakukan aksi swipe kanan atau kiri untuk melihat fitur utama dari aplikasi

2. Untuk masuk kedalam aplikasi, user dapat menekan tombol Masuk

3. Jika user belum memiliki akun, maka user dapat menekan tombol Daftar.

\section{Tampilan OnBaording}

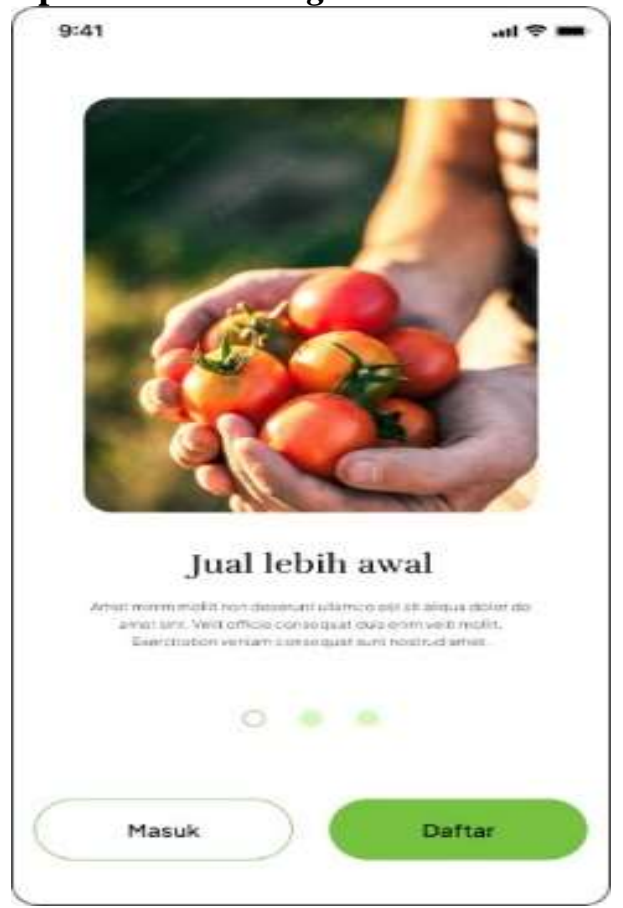

Gambar 3.1 Tampilan OnBoarding

Algoritma Tampilan Masuk

1. User melakukan input email dan password lalu menekan tombol Masuk

2. Jika user belum memiliki akun, maka user dapat menekan tombol Daftar.

\section{Tampilan Masuk}

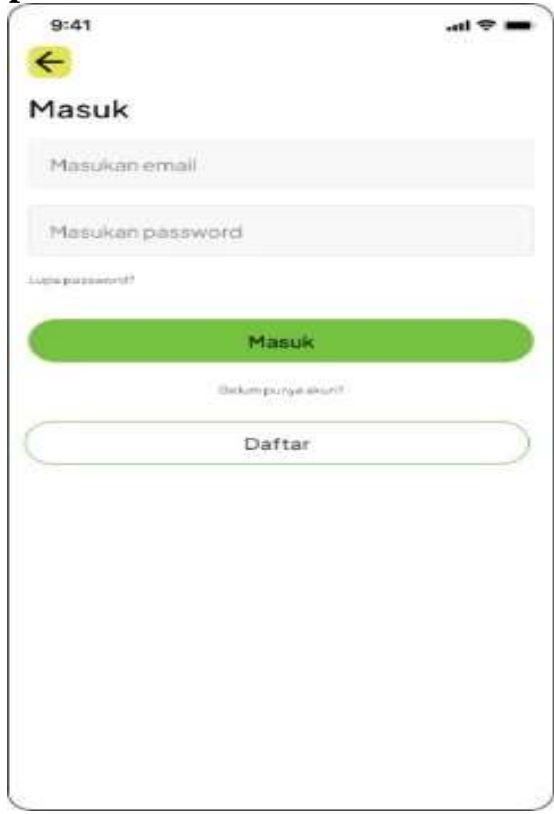

Gambar 3.2 Tampilan Masuk

Algoritma Tampilan Daftar

1. User melakukan input sesuai dengan data yang diperlukan pada halaman daftar

2. Jika semua data telah terisi dengan benar maka user dapat menekan tombol Daftar.

\section{Tampilan Daftar}

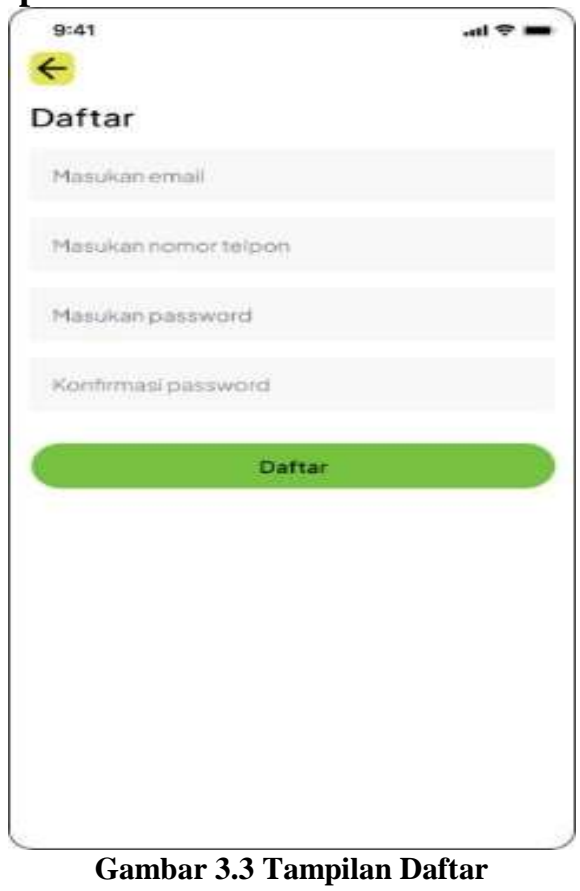

Algoritma Tampilan Halaman Utama

1. User dapat melihat berbagai macam kategori sayuran yang dijual

2. User dapat melakukan klik pada produk yang tampil 


\section{Tampilan Halaman Utama}

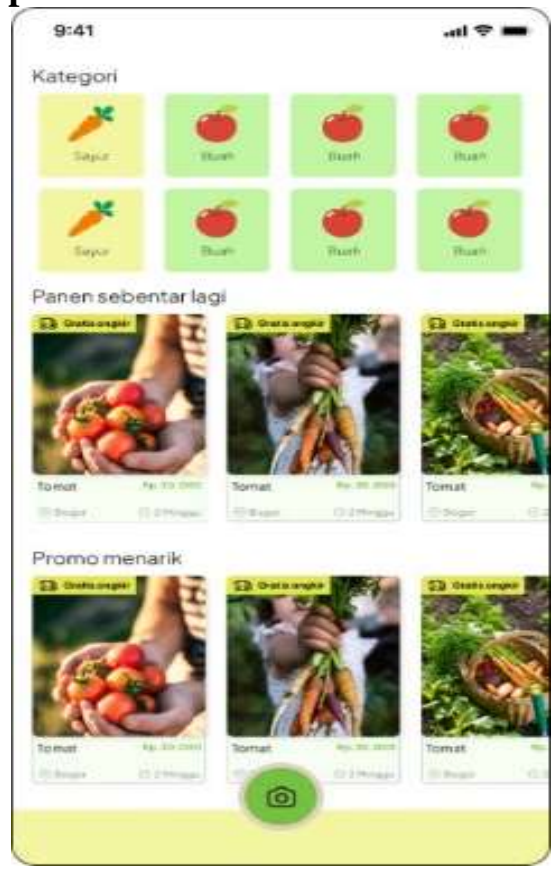

Gambar 4.1 Tampilan Halaman Utama

Algoritma Tampilan Detail Produk

1. User dapat menambahkan produk tersebut kedalam keranjang nya

2. User dapat menentukan jumlah dan satuan berat produk yang akan dibelinya

\section{Tampilan Detail Produk}

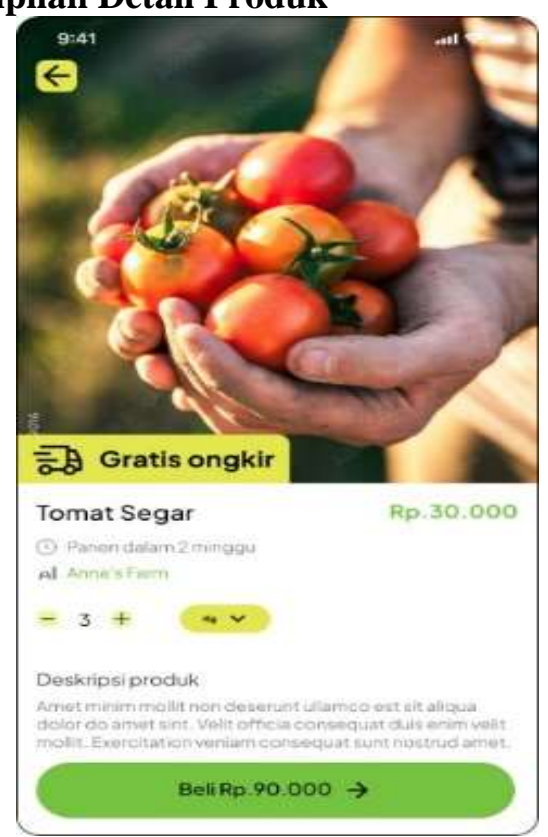

Gambar 4.2 Tampilan Detail Produk

Algoritma Tampilan Jual Produk

1. User melakukan input sesuai dengan data yang diperlukan pada halaman daftar

2. Jika semua data telah terisi dengan benar maka user dapat menekan tombol Jual.

\section{Tampilan Jual Produk}

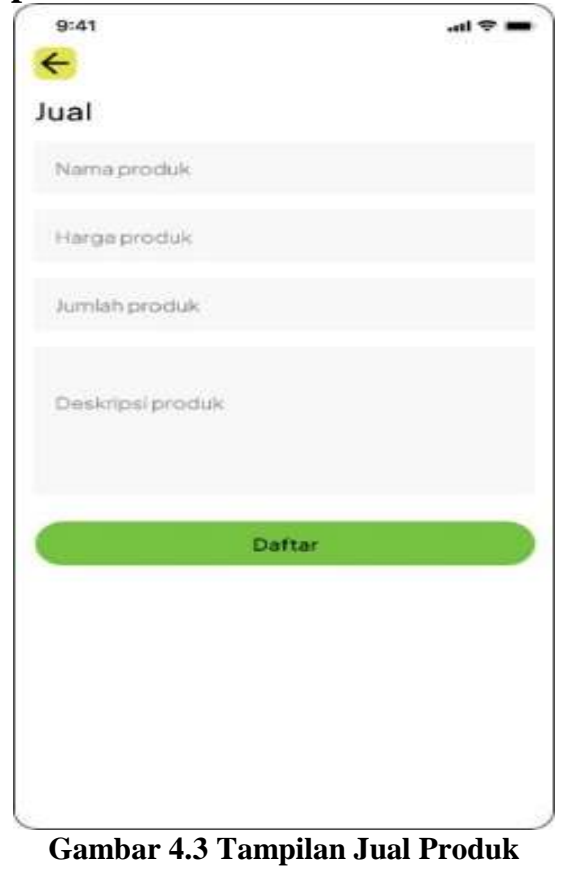

Algoritma Tampilan Keranjang

1. Menampilkan produk yang sudah user tambahkan ke keranjang nya

2. User dapat menekan tombol checkout

\section{Tampilan Keranjang}

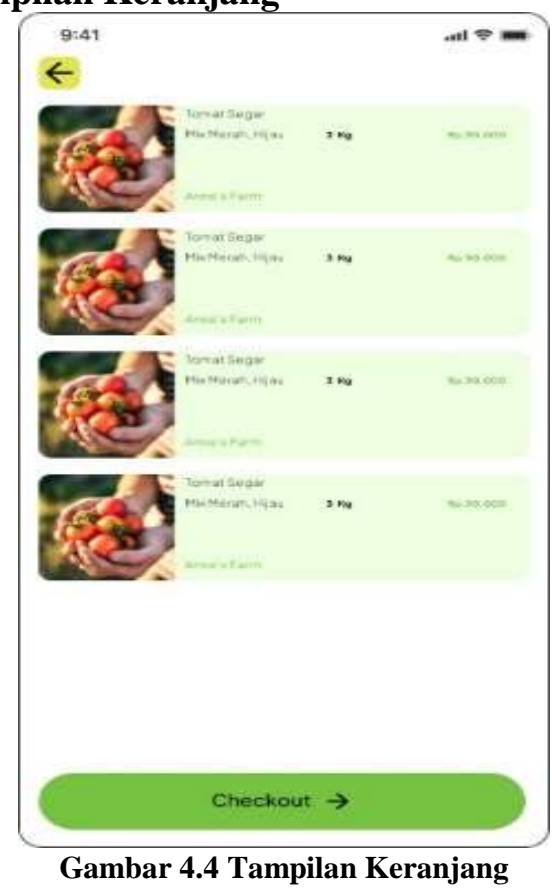

Algoritma Tampilan Pembayaran

1. Setelah menekan tombol checkout selanjutnya user akan diarahkan untuk memilih metode pembayaran

2. User dapat memilih metode pembayaran yang tersedia. 


\section{Tampilan Pembayaran}

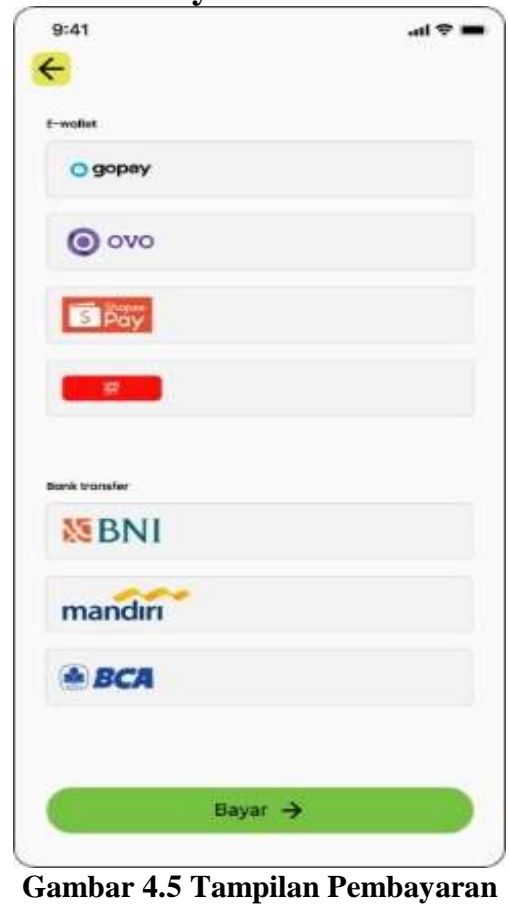

\section{SIMPULAN DAN SARAN}

Simpulan dari penelitian ini yaitu aplikasi telah berhasil dibangun dan berhasil dipasang pada smartphone dengan sistem operasi Lollipop keatas. Dalam aplikasi ini terdapat fitur untuk membuat akun baru, melihat produk hasil panen yang dijual, membeli hasil panen yang dijual serta tentu nya menjual hasil panen petani sayur ditampilkan dengan data berupa gambar dan teks dengan user interface yang menarik dan mudah untuk digunakan. Dengan adanya perancangan aplikasi penjualan hasil panen petani sayur di Indonesia ini penulis berharap dapat membantu petani dalam menjual hasil panen nya lebih cepat dan menjangkau lebih banyak pembeli agar kehidupan ekonomi petani tetap berjalan.

\section{DAFTAR PUSTAKA}

Albdulrohim, U., Gunawan, H., Herlambang, T., Bandung, S., Manajemen, S. T., Informatika, D., \& Bandung, K. (2015). Aplikasi E-Commerce Penjualan Hasil
Pertanian Tanaman Sayuran Berbasis Website Studi Kasus Di Balitsa Lembang. Jurnal Teknologi Informasi dan Komunikasi (Vol. 4).

Aliyah, I. (2017). Pemahaman Konseptual Pasar Tradisional Di Perkotaan.

Made, I., Surya Adinata, R., Tolle, H., \& Hendra Brata, A. (2019). Pembangunan Aplikasi Penjualan Hasil Panen Kelompok Tani untuk Konsumen Berbasis Android dengan Metode Prototyping (Studi Kasus: Kelompok Tani Langgeng Mandiri) (Vol. 3). Retrieved from http://j-ptiik.ub.ac.id

Nyoman, P., Sastra, S. T., Irsan, M. T., Saputra, S., Agung, A., Ngurah, I., Karyawati, E., et al. (2017). "Internet of Think (IoT) \& Big Data: Teknologi, Tantangan dan Pelu-ang" PENYUNTING AHLI.

Hansun, Seng., Kristanda, Marcel Bonar., \& Saputra, Michael Wijaya. 2016. Pemrograman Android Dengan Android Studio IDE. Tangerang : Andi.

Badan Pusat Statistik (2021, 17 Mei). Produksi Tanaman Sayuran. Diakses pada $17 \quad$ Mei 2021 dari https://www.bps.go.id/indicator/55/61/1 /produksi-tanaman-sayuran.

Statscounter Globalstats (2021, 4 Juni). Operating System Market Share Indonesia. Diakses pada 4 Juni 2021 dari https://gs.statcounter.com/os-marketshare/all/indonesia

Java T Point (2021, 12 Juni). Android Version. Diakses pada 12 Juni 2021 dari https://www.javatpoint.com/androidversions

Java T Point (2021, 13 Juni). JDK Java Development Kit. Diakses pada 13 Juni dari https://www.javatpoint.com/jdk

Kotlin (2021, 13 Juni) FAQ. Diakes pada 13 Juni 2021 dari https://kotlinlang.org/docs/faq.html

Zai, Jelistina Yolenta.2018.Aplikasi Jual Beli Hasil Pertanian Kopi Berbasis Web Menggunakan Google Maps API. Repository Universitas Sanata Dharma. 